\title{
Uang Kebon and Colonial Power Relations in East Sumatra Plantation
}

\author{
Tappil Rambe ${ }^{1}$, Leylia Khairani ${ }^{2}$ \\ \{tappilrambe98@gmail.com ${ }^{1}$,leyliakhairani@umsu.ac.id ${ }^{2}$ \}
}

\begin{abstract}
${ }^{1}$ Department of Historical Education, Universitas Negeri Medan, Jl. William Iskandar, Indonesia ${ }^{2}$ Department of Magister of Communication on Sciences, University of Muhammadiyah Sumatera Utara, Indonesia
\end{abstract}

\begin{abstract}
Colonialism in East Sumatra has been going on since the 19th century, which was initiated by the emergence and development of the plantation industry. In maintaining the power of the gardeners the practice of a binding power system for plantation workers. The colonialism system through the legitimacy of using uang kebon that prevails in the plantation environment reflects the hegemony of power of the colonialism system in plantations. The type of research used is qualitative research. The data source used in this study is the uang kebon archive which is a collection of the Museum Uang Sumatera. The results showed that there were differences in uang kebon and official currency used by the rulers of the Dutch East Indies. Money is used as the highest authority that not only acts as a medium of exchange (economic and monetary tools) but also as a political tool and the legitimacy of power (money power) to maintain power in the East Sumatra plantation area.
\end{abstract}

Keywords: Uang Kebon, Power Relations, East Sumatera, Colonialism

\section{Introduction}

Power is often represented as a form of domination of a subject or group legitimized by the State. This form of power is sometimes often practiced through repressive methods, oppression and state hegemony as a form of power. In this paper, the power represented by the state is seen from Foucalt's paradigm of power practiced not through violence, but in ways that enforce discipline to prevent other parties from dominating. That is, the authorities have a certain strategy in preventing others from being able to control the party that is being dominated. This method is commonly done, because, in the perspective of Foucalt's power, power is the authority or power of a person is an effort to achieve goals or maintain something.

Colonialism in East Sumatra was marked by the opening of plantations since 1867. The beginning of the opening of plantations in East Sumatra was initiated by a businessman named Nienhuijs. Over time, tobacco plantations have expanded due to high demand. So then in 1880, in East Sumatra, 88 private companies from Europe and other regions had been established [1]. As the plantation expanded, the number of coolies also increased, which was marked by the dominance of labor imports from Java and China, while also being imported from India (Tamil). Javanese workers are mostly brought in from poor villages in Central and East Java [1]. Subsequently in 1911 more than 50,000 contract coolies were imported from 
Central Java who was recruited from large coastal cities such as Semarang, Betawi and the royal regions of Yogyakarta and Surakarta, Purwerejo, and Banyumas [2]. In the era of colonialism, marked by the growth and development of plantation capitalism in East Sumatra, not only can it be seen from the coolie ordinance policy system, but also the policies and strategies that bind the plantation workers hereinafter referred to as coolies. Not only that, the embedding of the terms of the contract coolies is a product of the strategy of dividing the coolies who are often faced with positions of contention. Furthermore, another strategy is the division of labor and settlement clusters based on ethnicity. This has been done since the opening of the plantation period.

Workers who work on East Sumatra plantations are bound by binding contracts and regulated in coolie ordinances. The coolies work more than 10 hours, low wages, often accept other conditions such as wage deductions made by company leaders. Besides, gambling and prostitution systems are deliberately developed by the gardeners to ensnare and bind the coolies. The small wages earned a result in decades of poverty and dependence on plantations. Not only that, the wages given to workers in the form of coins (token money) can only be used and are valid in a plantation environment. This token is known as uang kebon.

All of these policies are other forms of labor inspection. The policies adopted by the gardeners in the plantation system both in the policies of the coolie ordinance and the economic system built through the circulation of currencies only apply to plantations which are interesting to be seen from the perspective of Foucalt's power theory. This perspective is used because of the compatibility of the rationale with some of the events obtained from the lives of the laborers on the plantation.

\section{Method}

The data source of this research is the collection of uang kebon at the Sumatra Money Museum. The existence of this money collection is evidence of events that occurred in the plantation economy system in the 19th century. The existence of the money is used as a primary data source to analyze the colonialism practices and power relations built on plantations. The analysis used is inductive analysis by observing various specific symptoms in primary data, then analyzed as general empirical data. This research is descriptive-explanatory with the ultimate goal to explain various specific symptoms related to the problems raised. In historical research, the method used is the process of critically testing and analyzing records and relics of the past [3]. This relevant method is used to analyze uang kebon which is used as a primary data source in this paper.

\section{Result and discussion}

The establishment of life on plantations is inseparable from the workforce brought in East Sumatra since the end of the 19th century [1], [2], [4], [5], [6], [7]. The pioneering figure in the opening of a plantation that made Deli a Land Hunter was Nienhuys. Deli is an area that has a promising expanse of land for investment in plantations. The arrival of Nienhuys to Deli on July 7, 1863, brought traces of civilization in Deli especially in Medan, because the development of investment in the plantation sector has an impact on infrastructure development as a support for the running of plantation capitalism.

Nienhuys is a pioneer of tobacco plantations that initially obtained land concessions from the Sultan Deli which are vast and free of rental fees. The land concession obtained is in the area between Deli River and Percut River which is located extending from the village of Mabar to Deli Tua, and is given over some time of up to 99 years [5]. From the results of the 
tobacco planted by Nienhuys, we get a good quality tobacco crop. As a world-class producer of high-quality tobacco, Deli has a positive impact in that its region has become the target of the development of plantation companies. In 1873 there were originally only 13 companies, then the following year had reached 23 plantation companies, and in 1876 had reached 40 plantation companies [1].

Speaking of plantations, can not be separated from the discussion of the plantation workers or often known as coolies. To develop and increase tobacco harvests, a large number of laborers are needed, plantation companies bring in hundreds of thousands of Chinese and Javanese workers, who are housed and fed in plantation barracks and bound as slaves [2]. These workers were brought in because the need for labor increased significantly as the plantations expanded. Recruitment of workers from outside is done because residents refuse to become plantation workers in their area. In addition, the objections of the residents became workers because the wages provided were not appropriate, the rejection of the policies imposed by the Sultan of Deli which gave concessions to the landowners of the estate passed the limits of power, and even communal land which for years had been worked as productive land for people's plantations.

Plantation laborers are various communities bound by the Koeli Ordonantie system. These policies and regulations are published periodically, from the first Staatsblad No. 133 from 1880 to staatsblad No. 421 in 1915. Koeli Ordonantie was created to organize a very large workforce. The policy issued in Koeli Ordonantie stipulates that workers are not allowed to violate the provisions stipulated by plantations, even though the regulation is detrimental to coolies. For example, coolies must work for 10 (ten) hours with a wholesale payment system, not daily. Rebellion, theft, and assault on the foreman and the owner of the garden because the work done by the workers is not under the wages earned. The wages earned by male coolies amounted to f 0.33 t.m f 0.38 one day, and female laborers f 0.28 . Wages can sometimes be deducted if workers make mistakes such as not completing their work [8]. So that it makes them continue to become plantation workers. The income earned by female workers is smaller than that obtained by men, which is half of the wages of male workers in 1894 [2].

The coolies who rebelled and fled will receive a sentence of forced labor without being given wages or adding to a contract extension. The items governing the punishment system for plantation workers are known as poenale sanctie (criminal sanctions). All coolies are automatically considered to agree when they sign a work contract that sometimes they do not know the contents of the contract signed by them. This regulation is a weapon for gardeners in binding their workers to obey all companies' orders and policies.

In addition to the labor system, the gardeners regulate the plantation life system which impacts the dependence of workers on the company. The construction of plantation life is a gambling, prostitution and opium system legalized by plantations. This prostitution system was deliberately created to bind the workers. The men who are entitled to a partner have been set by the garden master through the foreman. Fulfilling the sexual needs of households set by plantations for male workers by women determined by the foreman is not married. This was done because there are rules from the plantation which is a necessity that must be carried out as a consequence of the work system contract. Furthermore, legalized gambling was deliberately created by logging in addition to entertainment but also as an effort to create dependence on plantations. Because every day the payday arrives, the workers will spend their wages at the gambling table. This results in the workers will extend the contract because they are in debt to the plantation to meet their needs until the next payday arrives. This condition is a construction that was created as an effort by the landlords to continue to employ and continue to bind them to work ties. The legalized gambling and opium system resulted in 
plantation workers bound in this contract being forced to commit crimes that ended in giving penalties as a result of their actions.

In addition to the policy that binds the laborers constructed by the gardeners, there is also a policy of Christianizing Bataks in the Deli interior. The mission of Christianizing the people in the interior of the Deli area inhabited mostly by the Batak people as a strategy to secure the rebellion of the interior. With this intention Cremer in 1889 raised funds to help zending open several schools that must spread the world religion "civilized" [1].

Plantation policies that regulate plantation labor are not only through Koelie Ordonantie on work systems and labor violations but also relate to the social and cultural life of labor in the plantation environment. All of these policies were carried out and constructed by the gardeners to keep them bound in the working ties. This shows a condition that the source of life material continues to be monitored. This can continue to happen because local authorities give authority to the gardeners not only the use of land concessions but also the control and authority of the mastery of labor. The practice of colonialism through the use of money has been investigated by Restiyadi and Nasoichah from a Marxist perspective [9]. His research findings explain how the use of uang kebon is a binding tool to maintain power over workers through the plantation production system. From his article explained that the use of uang kebon is binding because it only applies to certain plantations. From the Marxist perspective, it is clear that the practice of power is a form of domination of a group represented by a class, in this case, the gardeners over economic control and material resources which are managed by plantation companies.

Each territory either the sultanate or the local kingdom, neighboring kingdoms, and the international world has a currency that is used as a medium of exchange or a means of payment. The currency used is a form of legitimacy and inauguration of an institution or institution such as the empire/kingdom and countries that implement the constitutional system which is a symbol of the triumph of his government. Each territory both the sultanate/kingdom and the state involved in international trade circulates its currency, or for smaller territories, it will use the royal currency that houses it.

Historically, money in the economic system of society is not only used as a medium of exchange, but as a means of defense of the power and sovereignty of a kingdom or state. In a kingdom's power system, sovereignty over territory can be determined by the extent to which currencies are produced and used as a medium of exchange in the trading system. One proof of sovereignty and economic and trade power through the use and production of currencies has been carried out by the Kingdom of Pasai, which according to Denys Lombard that the circulation of currencies produced by Pasai itself shows the era of triumph in the economic field [10].

Although in Deli there is the power of the Sultanate of Deli, plantation companies do not use currency circulating in the region. At the time when the practice of colonialism took place in East Sumatra, this region did not yet have the authority to print and distribute money. The currency in circulation is dominated by foreign currencies as a means of exchange of payment for export and import economic activities [11]. The economic development in East Sumatra is inseparable from the development of plantation commodities. This is indicated by the growing number of companies engaged in the real sector. The impact was on economic development which encouraged the entry of commercial banks.

In a developing economic system, several currencies are used as a medium of exchange, including the Spanish Real, the British Dollar Strait Settlement, Gulden (though less desirable). At the micro-level the company is to bind workers in the plantation sector, the employers, in addition to using employment contracts and various efforts to regulate and 
discipline workers, also issue payment instruments that are only valid in certain plantation company environments or known as cash. Aside from being a limited means of payment within the plantation area, this money is more of a means of supervising workers at the company. Uang kebon issued by the plantation is not accompanied by money changers so it cannot be used in public places. Uang kebon issued there are two types, namely coins and bill money made of paper.

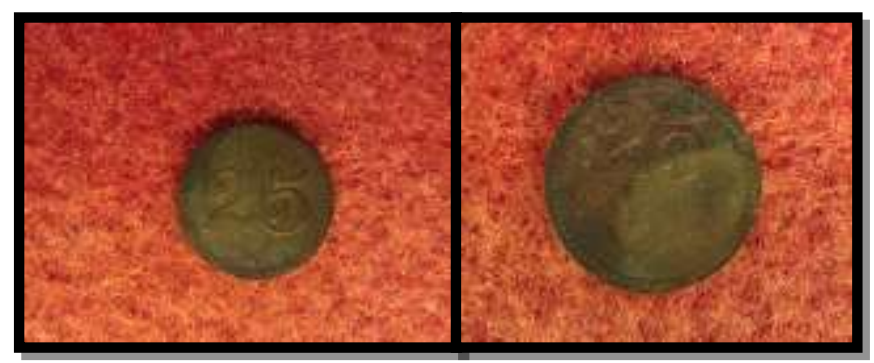

Fig.1. Uang Kebon with a value of 25 cents from the company Source: Van Steeden and Van Wijnen Source: Collection of Sumatran Money Museum

Entrepreneurs have a variety of ways to keep coolies "loyal" to the company. When payday arrives, a party is held at night. In this crowd porters used to gamble and go to brothels. This method effectively drains the bag of coolies that have just been filled. After running out of money, they were forced to sign a new work contract offered by the company. This habit continues.

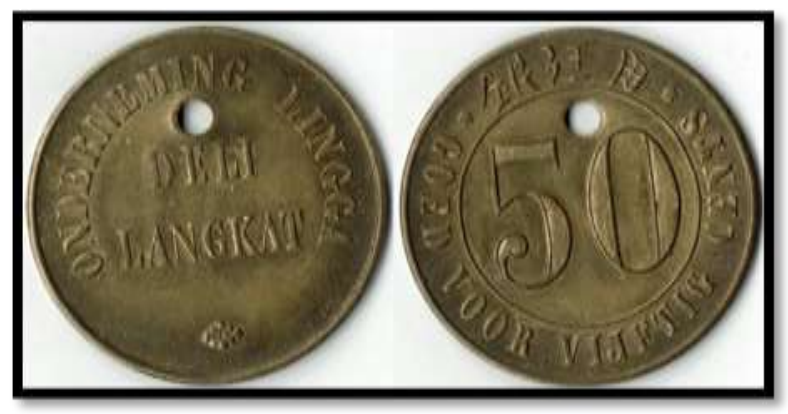

Fig.2. Uang Kebon with a value of 50 cents of Onderneming Lingga in Langkat Source: Collection of the Sumatran Money Museum

In the context of power, the practice of colonialism in the Deli estate represented a condition of class division, such as the ruling class (government Hindia Belanda), the capitalist class (the ruler of capital ie Europeans), the proletarian class (laborers or plantation laborers), and the local ruler (landowners). The use of uang kebon can be seen as a power relation between the landlord and the workers. Uang kebon is a symbol of the relationship between the capitalist class and the proletariat. This is shown through the practice of using uang kebon only in certain plantation areas which results in the attachment of the workers [9]. The power relations that are practiced by the gardeners to laborers or coolies are through 
employment contracts and Koeli Ordonantie which puts the coolies as workers who are bound in a certain period and subject to regulations made by plantations.

In Foucault's view, this can be understood as an effort to discipline and control thousands of workers and are very diverse. The power relations that were built between the landlord and the laborers during colonialism can be seen as a pattern of dependence between the holder of power (landlord) and those who are the object of power (labor). This power relation was born because the workers recruited were brought in from various poor villages in Java and other regions. Besides, the relation between the local authorities as landowners and the capital owners is European garden masters.

Although in this case, the landowner is also the owner of the material source, this party can not influence and intervene in policies made in the plantation system because there is legal fiction of the transfer of authority from local authorities to the landlord not only land but also labor [1]. From the accuracy that was built between the local authorities and the plantation, rulers benefited the local authorities through receiving tax from the harvest and extending the land lease. This system gives rise to an unbalanced pattern of dependency that brings an attitude of compliance [12].

The concept of Foucalt's power in seeing the phenomenon of using uang kebon in the practice of plantation colonialism is related to the practice strategy of maintaining power within the scope of plantation companies. The use of uang kebon can not only be seen as an effort to oppress or suppress the workforce but can also be seen as a form of regulation aimed at discipline. Power, in this case, is seen in a juridical context, such as linking power with sovereignty and law. In this conception, power is embedded or owned by certain individuals or groups in the hierarchy structure of power relations. This power is legally valid (legitimate) is exercised against others based on a consensus [13].

\section{Conclusion}

The power relations that are practiced through the circulation of uang kebon which are limited to companies in certain regions are not only seen as a symbol of the medium of economic exchange. But in Foucalt's perspective, it can be analyzed as a strategy to maintain the power of the gardeners in retaining their workers. From the perspective of Foucalt's power, the relationship formed between the landlord and the workforce is based on an agreement on work contracts (consensus) and is fully given his authority to the gardeners. Kebon earned by labor is a form of a consequence of services for the work they have completed. This has an impact on the relation of production from the farmer to the workers who provide wages for the work that has been done is considered as granting rights, other than that as a disciplinary effort carried out in every plantations company in Deli.

\section{References}

[1] Breman, J.: Menjinakkan Sang Kuli. Pustaka Utama Grafiti, Jakarta (1997).

[2] Stoler, A.: Kapitalisme dan Konfrontasi di Sabuk Perkebunan Sumatera, 1870-1979. Karsa, Yogyakarta (2005).

[3] Gosttchlak, L.: Mengerti Sejarah. Universitas Indonesia Press, Jakarta (2008).

[4] Pelzer, K.: Toean Keboen dan Petani. Sinar Harapan, Jakarta (1985).

[5] Said, M.: Koeli Kontrak Tempo Doeloe dengan Derita dan Kemarahannya. Waspada, Medan (1977).

[6] Geertz, C.: Involusi Pertanian Proses Perubahan Ekologi di Indonesia. Bharata, Jakarta (1976) 
[7] Lulofs, S.: Kuli. Grafiti Pers, Jakarta (1985).

[8] Soeara Djawa 1 Juni 1985

[9] Restiyadi, A dan Nasoichah, C.: Praktik Kolonialisme dalam Eksistensi Uang Kebon pada Perkebunan Sumatera Timur Abad ke 19-20. Vol.20 No.1, 1-17. Berkala Arkeologi Sangkhakala (2017).

[10] Lombard, D.: Kerajaan Aceh Jaman Sultan Iskandar Muda (1607-1636). Balai Pustaka, Jakarta (1986).

[11] No Name.: Berjuang dengan Uang Mempertahankan dan Memajukan Republik Indonesia: Semangat Juang Otoritas dan Masyarakat Sumatera Utara. Bank Indonesia (2016).

[12] Martin, R.: Sosiologi Kekuasaan. Rajawali Press, Jakarta (1995).

[13] Kamahi, U: Teori Kekuasaan Michel Foucalt: Tantangan bagi Sosiologi Politik. Vol. III, No. 1, Juni 2017. Jurnal Al-Khitabah 